\section{ORGANIZATION OF SCIENTIFIC AND INDUSTRIAL RESEARCH IN INDIA}

$\mathrm{T}$ WO articles on the Government organization of scientific and industrial research in India appear in the July issue of Science and Culture. One of these describes the present organization, which now comprises the Board of Scientific and Industrial Research, the Council of Scientific and Industrial Research, the Industrial Research Utilization Council and the Committee for the Publication of a Dictionary of Raw Materials. The Council is the supreme body, the Board having now been reduced to the position of an advisory body for scrutinizing schemes of scientific research. A large number of sub-committees are appointed from time to time to act as auxiliary advisory sub-committees to the Board and Council, while the Industrial Research Utilization Council advises on the utilization by the industries of researches completed by the Board. The Board maintains a research laboratory which was transferred to Delhi in 1942.

The article, in a critical review, directs attention to the defects of the present organization, notably the overlapping in the functions of the officers and the absence of co-ordination, the complicated procedure for dealing with research schemes and proposals, and the absence of any continuous programme of research and of a national laboratory. The writer of the article contrasts the development of the organization with that of the Department of Scientific and Industrial Research in Great Britain, drawing freely on an article marking the twenty-fifth anniversary of the Department which appeared in NATURE of May 11, 1940, and stresses the importance of administration being in the hands of professional scientific men, of enlisting the active co-operation of all scientific talent in the country, of establishing numerous research laboratories for the study of subjects of national importance which cannot be carried out in the university laboratories, and of encouraging researches in pure sciences and raising a large research personnel by the establishment of many research fellowships and stipends under university professors.

The second article outlines proposals for reform. A Department of Scientific and Industrial Research, with the status and rank of an "Attached Department" to the Commerce Department of the Government of India, should be constituted. The principal executive officer should be a full-time secretary who should be a senior scientific man with administrative abilities and a good record in scientific research. The Council of Scientific and Industrial Research should be the parent body, and its functions should be to lay down broad features of policy, receive grants from the Government and consider the reports of the Scientific and Industrial Advisory Boards. It should encourage and promote scientific and industrial research, suggest measures for the development of agriculture and industries, and promote scientific works of national importance. The Council should be assisted by two principal advisory boards, taking the places of the present Board of Scientific and Industrial Research and the Industrial Research Utilization Council, respectively. The Scientific Advisory Board should have a distinguished nonofficial scientific man as chairman and members drawn from eminent men of science representing different sciences, and should be the principal body for supervising and laying down programmes for scientific and industrial research, with a scientific man as full-time secretary.

The present research committees should be reorganized, with separate secretaries, and should prepare the programmes of research in their respective fields for the guidance of the Scientific Advisory Board. 'The research institutes should be under the direct supervision of the Department, and the directors of research would be directly responsible to the Council and act as secretaries of the respective governing bodies of their Institutes. The Industrial Advisory Board should be the main body for advising on all matters concerning the utilization of researches, establishment of new industries, etc., with a nonofficial industrialist as chairman and an industrial economist as secretary. The Industrial Exploratory Committees should be under the Industrial Advisory Board. There should be a board of assessors for sanctioning the work of the various bodies and laboratories under the Department with a membership of industrialists, scientific men, representatives of Government Departments concerned and some members of the Legislature.

\section{CONTROL OF THE INSECT ENEMIES OF LAC}

T'T is estimated that insect enemies destroy about 140 per cent of the total lac crop in India every year. The importance of this feature is all the greater for the reason that the people affected by the loss are mainly the poorest cultivators of the country. The chief insect enemies are predators and parasites: the first-named include the larvæ of two species of moths and the parasites are represented by more than eight species of Chalcid wasps. There are three general methods of controlling such enemies-biological, cultural and artificial controls. The principle of biological control has not so far been adequately investigated as regards the lac insect. Cultural methods, although useful, have greater limitations. Artificial methods, on the other hand, are valuable either independently or in conjunction with either of the other two methods. With regard to artificial control, fumigation is a well-known and efficient means, but it is not possible for the Indian cultivators to resort to it unless properly organized fumigation centres are maintained by an outside authority in every village or group of villages. The other method of artificial control is water-immersion.

This subject is discussed by P. S. Negi in Bulletin No. 50 (1942) of the Indian Lac Research Institute. The advantage of this means of control is its ease of application, involving practically no extra expense. It requires only water for immersion and sunshine for the subsequent drying of the lac. It is recommended that the shoots bearing the lac be submerged to a depth of at least two feet for a period of three. days either in running water or in stagnant pools This procedure prevents a large number of insect enemies emerging from the lac when stored. The lac is, moreover, more easily scraped from the twigs after such immersion. Shellac manufacture, and physical as well as chemical tests, show that the yield and properties of shellac are not adversely affected by the water-immersion. 


\section{FORTHCOMING EVENTS}

(Meetings marked with an asterisk * are open to the public)

\section{Monday, November 29}

Royal Society of ARts (at John Adam Street, Adelphi, London, W.C.2), at 1.45 p.m.-Mr. H. A. Cox : "Timber-Úses New and Old" (Cantor Lectures, 2).

Association of Austrian Engineers, Chemists and Scientific WoRkERs 69 Eton Avenue, Hampstead, London, N.W.3), at 7.15 p.m.-Mr. John F. Shipley: "The Role of Meteorology in Engineering Enterprise"'.

Tuesday, November 30

Institution of Civil Engineers (Structural and Building ENGINEERING Division) (at Great George Street, Westminster, Lon don, S.W.1), at 5 p.m.-Dr. Oscar Faber: "Difficulties Encountered and Overcome in connexion with Constructional Works".

ROYAL INSTITUTION (at 21 Albemarle Street, London, W.1) at 5.15 p.m.-Prof. J. C. Drummond : "Food Problems of the Post-War Years" 2: "Food Research"."

\section{Wednesday, December I}

ROYaI Societr of ARTs (at John Adam Street, Adelphi, London, W.C.2) at 1.45 p.m-Mrs, Goldsworthy: "Education To-day and To-morrow", 2: "Nursery and Infant Schools".

SOCIETY OF CHEMICAL INDUSTRY (FOOD GROUP) (joint meeting with the SocIETY OF PUBLIC ANALYSTS) (at the London School of Hygiene and Tropical Medicine, Keppel Street, Gower Street, London, W.C.1), Hughes: "Nutrition of the Public and Food Legislation".

Geological SocIETY of London (at Burlington House, Piccadilly, London, W.1), at 3 p.m.- Scientific Papers.

Institution of ELECTRICAL ENGINEERS (WIRELESS SECTION) (at Savoy Place, Victoria Embankment, London, W.C.2), at 5.30 p.m."A Basis for the Prediction of Performance of Hearing Aids".

\section{Thursday, December 2}

BRITISH SOCLETy FOR INTER NATIONAL BiBLIOGRAPHY (at the Scienco Museum, Exhibition Road, South Kensington, London, S.W.7), at 2.15 p.m.-Symposium on "Film Classification, Conservation and Projection".

ROYAL INSTITUTION (at 21 Albemarle Street, London, W.1), at 2.30 p.m.- Prof. W. Perceval Yeats: "Links between Ancient China and the West: a Study of Exchanges in Material Culture", 2 . "Ancient Commerce with the West".

CHEMICAL SOCIETY (joint meeting with the UNIVERSITY College Physical AND CHEMICAL SocIeTY) (in the Chemistry Lecture Theatre, University College, University Park, Nottingham), at 4 p.m.-Dr. H. J. Emeleus: "Some Properties and Reactions of Anhydrous Hydrofluoric Acid".

\section{Friday, December 3}

Association of APPLIED BIologists (at the London School of Hygiene and Tropical Medicine, Keppel Street, Gower Street, London, W.C.1), at 11.15 a.m.-Discussion on Slugs (to be opened by Mr. K. F. Barnes and Mr. D. C. Thomas).

ROYaL INSTITUTION (at 21 Albemarle Street, London, W.1), at 5 p.m. -Dr. C. C. Paterson, F.R.S.: "Dies from Diamonds and their Use: a Triumph of Technical Precision".

Institution of MEchanical Enginears (APplied MEChanics GrouP) (at Storey's Gate, St. James's Park, London, S.W.1), a 6 p.m.-Dr. L. Fox and Dr. R. V. Southwell, F.R.S. : "On the Stresse in Hooks and their Determination by Relaxation Methods"

Chemical Sociery (at the Royal Technical College, Glasgow), at 7.15 p.m.-Prof. G. M. Bennett: "Some Aspects of the Formation of Ring Compounds".

\section{Saturday, December 4}

Geologists' Association (at the Geological Society, Burlington House, Piccadilly, London, W.1), at 2.30 p.m.-Dr. Alan Wood : "Basic English and its use in Geology" and "Organs of Reproduction in the Solenoporacece".

SHEFFIELD MeTALLURGICAL ASSOCIATION (joint meeting with the SHEFFIELD SOCIETY OF FNGINEers AND METALLURgis's and the SHEF AND STEEL INSTITUTE) (at the Royal Victoria Station Hotel, Sheffield), at 2.30 p.m.-Discussion on the Fourth Report of the Oxygen Sub-Committee.

\section{APPOINTMENTS VACANT}

APPLICATIONS are invited for the following appointments on or before the dates mentioned :

TECHNICAL OFFICER to work in a particular district of the countyThe Secretary Berkshire War Agricultural Executive Committee 1 Abbot's Walk, Reading (December 3).

EDUCATIONAL' PSYCHOLOGIST-The Secretary for Education, Education Offices, York (December 4).

LABORATORY TECHNICIAN FOR THE VETERINARY LABORATORYThe Secretary, Edinburgh and East of Scotland College of Agriculture, 13 George Square, Edinburgh (December 7)

VETERINARY OFFIOERS to fll vacancies in Government and other services in New Zealand-The High Commissioner for New Zealand 415 Strand, London, W.C.2 (December 13).
REGIUS PROFESSOR OF ZoOLOGY at Glasgow University-The Private Secretary, Scottish Office, Fielden House, 10 Great College Street, London, S.W.1 (January 17)

ASSISTAN' WORKS MANAGER (AERO-ENGINES) for Royal Air Force epairs in India-The Ministry of Labour and National Service, Central (Technical and Scientific) Register, Alexandra House, Kingsway, London, W.C.2 (quoting Reference No. C.1525.A).

PiIr Crist fabour and National Service, Central (Technical and Scientific) Register, Alexandra House, Kingsway, London, W.C.2 (quoting Reference No. F.1790)

IECTURER (Honours graduate) IN MECHANICAL ENGINEERING, and a (Ho Mathematics-The Secretary, LECTURER (Honours graduate) IN MATHEMATICS

ASSISTANT MASTER (graduate) FOR MATHEMATICS; SCIENCE AND ASSISTANT MASTER (graduate) Fon MAnior Technical School for Boys-The Director of Education, 8 Warrington Street, Ashton-underLyne, Lancs.

METALWORK INstructor-The Principal, South Dorset Technical College, Newstead Road, Weymouth.

SCIENCE GRADUATE (Reading or Swanley preferred) to teach GENERAI Sorence part-time in Day Technical School for Girls and Produo SUBJECTS to Women's Institutes in area of East Kent-The Principal, Technical Institute, Longport Street, Canterbury.

DESIGNER OF VENTILATION EQUIPMENT required by the Admiralty -The Ministry of Labour and National Service, Central (Technica and Scientific) Register, Advertising Section, Alexandra House, Kings way, London, W.C.2 (quoting Reference No. C.1874A).

\section{REPORTS and other PUBLICATIONS}

(not included in the monthly Books Supplement)

Great Britain and Ireland

London Bird Report for 1942: an Annual Report on Bird-Lif within Twenty Mijes of St. Paul's Cathedral. Edited by R. S. R. Fitter and E. R. Parrinder. Pp. 24. (London: London Natura History Society, c/o London School of Hygiene and Tropical Medicine. 18. $6 d$. Bibliography of Meteorological Literature. Prepared by the koyal office Vol 5, No 4, July-December 1942. Pp. ii +47-70. (London Royal Meteorological Society.) 2s. 6d.
British Association : Committee on Post-War University Education.
[1910 A Note on Universities and the Education of Teachers. Pp. 9. (London : British Association.) 6d. Federation of British Industries. Industry and Research: Report the F.B.I. Industrial Research Committee. Pp. 24. (London: Federation of British Industries.) Scientific Proceedings of the Royal Dublin Society. Vol. 23 (N.S.) No. 16: Atmospheric Pollution in Dublin during the Year 1942 By A. G. G. Teonard, Bridget P. McVerry and D. Crowley. Pp. 164By A. G. G. Leonard, Bridget P. McVerry and D. Crowley. Pp. Norgate, Ltd.) 1s.

\section{Other Countries}

Commonwealth of Australia: Council for Scientific and Industria Commonwealth of Australia : Council for Scientific and Industrial cum perforatum I. var. angustifolium D.C.) by Competing Pasture Plants. By R. M. Moore and A. B. Cashmore. Pp. $23+5$ plates Bulletin No. 156 : Standardized Plant Names ; a List of Standardized Common Names for the more Important Australian Grasses, othe Pasture Plants, and Weeds. Pp. 99. Bulletin No. 160: The Outbrea of the Australian Plague Locust (Chortoicetes terminifera Walk.) in th Season 1939-40, with Special Reference to the Influence of Climatio Factors. By Dr. K. H. L. Key. Pp. 40. Bulletin No. 163: Trans mission of Potato Virus Diseases. 1 : Field Experiment with Lea The At Canberra, 1940-41, by Dr. J. G. Bald and D. O. Norris ; 2 : D. O. Norris and Dr. J. G. Bald. Pp. 32. Industrial Chemistry Circular No. 2: Investigation of Low-Tin and Tin-Free Solders. By. W. Worner, H. $\mathrm{H}$. Greenaway and J. H. Buckley. Pp. 16. Industrial Chemistry Circular No. 3 : Melting and Casting of Magnesium Alloys. By H. A. Stephens. Pp. $28+4$ plates. (Melbourne: Govern [210 Asutosh Museum Series No. 2: Museum Method and the Proces of Cleaning and Preservation. By Minendra Nath Basu. Pp. viii +36 (Calcutta: University of Calcutta.) Report of the Haffkine Institute for the Years 1940 and 1941.
By Lieut,-Colonel S. S. Sokhey. Pp. ii +84 . (Bombay: Government By Lieut.-Colonel S. S. Sokhey. Pp. ii +84 . (Bombay : Government [ndia.) 6 annas; $8 d$.
Indian Association for the Cultivation of Science. Annual Report for the Year 1942. Pp. 18+22. (Calcutta: Indian Association for [218 Smithsonian Institution. War Background Studies, No. 14 : Islands and Peoples of the Indies. By Raymond Kennedy. (Publication 3734.) Pp. iv $+66+21$ plates. (Washington, ].C. S Smithonian Proceedings of the American Philosophical Society. Vol. 86, No. (September 25, 1942): The Early History of Science and Learnin in America : Papers read before the American Philosophical Societ Midwinter Meeting, February 13-14, 1942. Pp. iv +204. Vol. 87, No. 3 (July 14, 1943) : Thomas Jefferson; Papers read before the American Philosophical Society in celebration of the Bicentennial of Thomas Jefferson, Third President of the Society, Annual Meeting, April 22, 23 and 24,1943 . Pp. iii $+199-290+7$ plates. (Philadelphia:
American Philosophical Society.)

\section{Catalogue}

A Catalogue of Books on a Variety of Subjects suitable for Presentetion together with a selection of New and Recent Books. (No. 615.) Pp. 24. London: Bernard Quaritch, Ltd.) $1 d$. 